\title{
SOME PROBLEMS ARISING FROM GOVERNMENT CORPORATIONS
}

\author{
By O. R. McGuIRE $\dot{\hat{i}}$
}

The use of the corporate device as a means of executing functions of the Federal Government has grown considerably through the years. Although the device is not new in this country, ${ }^{1}$ recent years have seen a much more extensive use of it. $^{2}$ This paper will be devoted to suggestions of constitutional problems and a discussion of the legal status of some of the more important government corporations in particular situations. Although there is comparatively little literature or case law ${ }^{3}$ on the subject, nevertheless, it represents such an important element in our modern form of government that an indentation must be made somewhere.

Government corporations have been created either by direct act of Congress, by act of the executive establishing the corporation under a state incorporation law, or by purchase by the Government of all of, or a controlling interest in, a private corporation, thereby transforming it into a government corporation.

Shortly after the Revolution the Federal Government created by its own charter the Bank of North America and later the First and Second Banks of the United States. However, inasmuch as the Government did not control or manage these corporations, or hold a majority of the stock, ${ }^{4}$ they should not strictly be classed as government corporations. Likewise national banks ${ }^{5}$ and railroads ${ }^{6}$ which have been incorporated by Congress should be classed as private corporations, because the management is in private individuals and the corporations are operated for profit. ${ }^{7}$ The first corporation really resembling the New Deal corporations was the Panama Railroad Company which was acquired by the Federal Government in

† A. B., I9I7, Louisiana State University; A. M., I9I9, LL. B., I92I, The George Washington University; S. J.D., 1923, The American University. Member of the Virginia Bar; Chairman, Special Committee on Administrative Law, American Bar Association, and ViceChairman, Committee on Administrative Laws, Federal Bar Association. Assisted by W. W. Spear, member of the District of Columbia Bar.

I. I Davis, Essays in Earlier History of Amerucan Corporations (igI7) 49 ; McGuire, Govermment by Corporations (I928) I4 VA. L. REv. I82; Osgood, The Corporation as a Form of Colonial Government (I896) II PoL. Scr. Q. 259.

2. Atwood, The New Deal Corporate Maze (I935) 208 Sat. EvE. Post, Oct. 26, p. 23.

3. Richmond Fairfield Ry. v. United States Housing Corp., 72 F. (2d) 78 (App. D. C. 1934); California v. United States, 75 F. (2d) 4I (C. C. A. 9th, 1935) ; Powell, National Taxation of State Instrumentalities (I936) 20 ILL. STUdIES IN SOc. ScIENCES no. 4, p. I.

4. VAN Dorn, Goveringent OWNed Corporations (I926) 230, 231.

5. I3 STAT. 100, IOI (I864), I2 U. S. C. A. \$\$2I, 24 (I934).

6. See California v. Central Pac. R. R., I27 U. S. I, 39-40 (I888).

7. See McIntire, Government Corporations as Administrative Agencies: An Approach (r936) 4 Geo. Wash. L. Rev. I6I. 
I904. ${ }^{8}$ The United States bought nearly all of the stock of the Company and has operated it ever since. The Company was originally incorporated under the laws of the State of New York in I849 and operates as such today. ${ }^{9}$ The stock of the Alaska Northern Railway Company was acquired by virtue of an act authorizing the President to locate and operate railroads in Alaska. ${ }^{10}$ This corporation has been held to be a government corporation and also a government department, possessing the attributes of sovereignty of the United States. ${ }^{11}$

Beginning with the World War the corporate device was used in several instances, although the reason for this use of corporations instead of the more usual governmental departments and bureaus was not entirely clear. ${ }^{12}$ At this time the United States Emergency Fleet Corporation, ${ }^{13}$ the United States Grain Corporation, ${ }^{14}$ the United States Housing Corporation, ${ }^{15}$ the War Finance Corporation, ${ }^{16}$ the Sugar Equalization Board, ${ }^{17}$ the Spruce Production Corporation, ${ }^{18}$ and the Russian Bureau, Incorporated, ${ }^{19}$ were formed. After the War and up until I93I the United States established the Federal Intermediate Credit Banks ${ }^{20}$ and the Inland Waterways Corporation. ${ }^{21}$ The more recent government corporations will be classified functionally in order to facilitate a discussion of the problems involved. ${ }^{22}$

\section{Corporations Concerned with Credit and Finance}

The Reconstruction Finance Corporation was created by act of Congress early in $1932 .{ }^{23}$ It is authorized to aid in financing agriculture,

8. 32 Stat. 48 I, 484 (I902), 3I U. S. C. A. \$744 (I934). For litigation involving this corporation, see Panama R. R. v. Minnix, 282 Fed. 47 (C. C. A. 5th, I922) ; Rogers v. Graves, 57 Sup. Ct. 259 (U. S. 1937) (holding that the salary received by an employee of the Panama Railroad Company was immune from state taxation).

9. Dimock, Government-operated EnTerprises in the Panama Canal Zone (I934).

Io. 38 Stat. 305 (I9I4), 48 U. S. C. A. $\$ \$ 30 I-308$ (1934).

II. Ballaine v. Alaska N. Ry., 259 Fed. I83 (C. C. A. 9th, I9I9).

12. Reed, Government-oumed Business Corporations (I935) 2 U. S. L. WEEK 1039.

13. The United States Shipping Board was created by 39 Star. 729 (I916), 46 U. S. C. A. $\$ 804$ (I934). It in turn incorporated the Fleet Corporation under the laws of the District of Columbia.

I4. Created by EXEc. ORDER No. 268r, Aug. I4, I9I7, resulting from the general language of the Food Control Act. See VAN DoRN, op. cit. supra note 4, at 8I. at 139 .

15. Organized by the Secretary of Labor under the Laws of New York in Igr8. Id.

I6. Created by Congress, 40 Srat. 506 (Igr8), I5 U. S. C. A. \$\$ 331-373 (I934).

17. Created by Herbert Hoover as Food Administrator in 1918 under the laws of Delaware with the approval of the President. VAN DORN, op. cit. supra note 4 , at I78.

I8. The corporation was authorized by Congress, but was chartered under the laws of the State of Washington by the Director of Aircraft Production. Id. at 249.

19. Incorporated in Connecticut by the War Trade Board in I9I8. Id. at 255.

20. 42 StAт. I454 (I923), I2 U. S. C. A. \$ I02I (I934).

2I. 43 STAT. 360 (I924), 49 U. S. C. A. \$ I53 (I934).

22. For a more detailed survey of the New Deal government corporations see Culp, Creation of Government Corporations by the National Government (I935) 33 MICH. L. REv. 473 (excerpts from the certificates of incorporation of the various New Deal corporations); McIntire, supra note 7.

23. 47 Stat. 5 (I932), 15 U. S. C. A. §6or (Supp. 1936). The 75th Congress passed a bill to create a corporation designed to be subsidiary to the $R$. F. C. to render relief in the flood-stricken areas by means of unsecured loans. As yet the bill has not been signed. 
banking, commerce, industry, state insurance funds, and states and municipalities. The Commodity Credit Corporation was incorporated under the laws of Delaware pursuant to an executive order. ${ }^{24}$ It is authorized to deal in agricultural or other commodities, to loan on them, to encourage farmers in marketing, and to do anything designed to carry out the purposes of the N. R. A. ${ }^{25}$ Both of the Export-Import Banks of Washington were organized by executive order under the laws of the District of Columbia. ${ }^{26}$ They carry on a general banking business designed to facilitate exports and imports. The Tennessee Valley Associated Cooperatives, Inc., was created under the laws of Tennessee by three directors of the Tennessee Valley Authority. The purpose of the corporation is " " to promote, organize, establish, manage, finance, coordinate, and assist in any way whatsoever' in the development of cooperative enterprises in the Tennessee Valley Authority area." 27

Several government corporations were created to aid agricultural reconstruction, among which are the Farm Mortgage Corporation, ${ }^{28}$ Production Credit Corporations, ${ }^{29}$ the Central Bank for Cooperatives, ${ }^{30}$ and Regional Banks for Cooperatives. ${ }^{31}$ For the aid of the home owner there is the Home Owners' Loan Corporation, ${ }^{32}$ which subscribes to the stock of the Federal Savings and Loan Insurance Corporation, ${ }^{33}$ its purpose being to insure the accounts of eligible building and loan associations. In the same category are the Federal Home Loan Banks, ${ }^{34}$ Federal Savings and Loan Associations, ${ }^{35}$ National Mortgage Associations, ${ }^{36}$ and Federal Credit Unions. ${ }^{37}$

\section{Corporations Concerned with Development and Relief}

The Tennessee Valley Authority is perhaps the most important agency under this heading. Formed by act of Congress in $1933{ }^{38}$ it is intended to be a permanent agency. The Authority has formed under the laws of Delaware the Electric Farm and Home Authority, Inc., which is a subsidiary mortgage-loan company of the T. V. A. ${ }^{39}$ Another corporation coming

24. EXEc. ORDER No. 6340, Oct. I7, I933.

25. Cert. of Incorp., Art. 3, in Culp, supra note 22, at 484, n. 23.

26. Exec. Order No. 6581, Feb. 2, I934; Exec. Order No. 6638, Mar. 9, I934.

27. U. S. Gov't MANUAL (I935) 285.

28. 48 Stat. 344 (1934), I2 U. S. C. A. § I020 (I934).

29. 48 Stat. 257 (I933), I2 U. S. C. A. §II3I (I934).

30. 48 Stat. 26I (I933), I2 U. S. C. A. \$II34 (I934).

3r. 48 Stat. 257 (I933), I2 U. S. C. A. §II34 (I934).

32. 48 StAт. I29 (I933), 12 U. S. C. A. \$ 1463 (1934).

33. 48 Stat. I256 (I934), I2 U. S. C. A. § I725 (I934).

34. 47 Stat. 726 (I932), I2 U. S. C. A. \$ I 423 (I934); see I U. S. L. WeEK (I934) 648.

35. 48 StAT. I32 (I933), I2 U. S. C. A. $\$ 1464$ (I934); see (I933) I U. S. L. WEEK I82.

36. 48 Stat. I252 (I934), I2 U. S. C. A. \$ I716 (1934).

37. 48 STAT. I216 (I934), I2 U. S. C. A. § I752 (1934).

38. 48 STAт. 58 (1933), I6 U. S. C. A. §83I (Supp. I936).

39. Subsequently reorganized under the laws of the District of Columbia. 
within this classification is the Federal Subsistence Homesteads Corporation, created under the laws of Delaware by order of the Secretary of the Interior in I933. The purpose of this corporation is "To aid the redistribution of the uverbalance of population in industrial centers by making loans for and otherwise aiding in the purchase of subsistence homesteads." $4^{\prime 0}$ Differing somewhat from these corporations is the Prison Industries Corporation which was formed by the Attorney General under the laws of the District of Columbia pursuant to statutory authority to conduct various industries in the Federal prisons. This is a very important Federal corporation and is unique in that the statute authorizing its incorporation specifically provides that its expenditures shall be made so far as practicable in accordance with the law governing other expenditures by the Federal departments and establishments of the United States. ${ }^{41}$ In any discussion concerning the power of the Federal Government to create corporations we must always bear in mind the oft-repeated fundamental of constitutional law that the Federal Government is one of delegated powers. ${ }^{42}$ It must be taken as settled that the Federal Government has the power to create a corporation for the purpose of carrying out the powers given to it by the Constitution. The wellknown case of $M c C u l l o c h v$. Maryland ${ }^{43}$ first laid down the principle that, although the words "bank" or "incorporation" did not appear in the Constitution, the Congress was justified in creating a corporation as a means for executing the enumerated powers.

Since it is proper for Congress to create corporations for the execution of its enumerated powers, the next question is just what kind of government corporations may Congress create? The few cases on the subject tell us that the Federal Government may incorporate private corporations to construct a bridge between two states, ${ }^{44}$ to build railroads, ${ }^{45}$ to establish national banks ${ }^{46}$ and to construct a canal in the District of Columbia. ${ }^{47}$ It is important to remember that these corporations were not controlled by the government and were not for the exercise of Federal power. The management was left to private individuals and the corporations were operated for profit. Apparently there have been only two cases bearing directly upon the question of the power of Congress to create government corporations in the sense of government-managed corporations. The first, as already indicated, was McCulloch v. Maryland. The other was Smith v. Kansas City

40. Cert. of Incorp., art. 3. For copies of this and several other charters see 79 Cong. REC. I552-I 56I (I935).

4I. 48 Stat. I2II (1934), I8 U. S. C. A. \$ 744 (Supp. I936).

42. United States v. Butler, 297 U. S. I, 63 (I936).

43. 4 Wheat. 3 I6 (U. S. I8Ig).

44. Luxton v. North River Bridge Co., I53 U. S. 525 (1894).

45. California v. Central Pac. R. R., I27 U. S. I (I888).

46. Farmers' and Mechanics' Nat'l Bank v. Dearing, 9I U. S. 29 (I875).

47. Georgetown v. Alexandria Canal Co., I2 Pet. 91 (U. S. I838). 
Title \& Trust Company, ${ }^{48}$ where Congress had chartered Federal Land Banks under federal law, ${ }^{49}$ the government then holding part of the stock temporarily. The government had majority control of the board of directors, ${ }^{50}$ so that it was properly to be classed as a government corporation. The Court sustained the power of Congress to create such banks saying:

"Since the decision of the great cases of McCulloch $v$. Maryland . . . and Osborn v. Bank . . . , it is no longer an open question that Congress may establish banks for national purposes, only a small part of the capital of which is held by the Government, and a majority of the ownership in which is represented by shares of capital stock privately owned and held; the principal business of such banks being private banking conducted with the usual methods of such business." 51

The holding was based almost entirely upon the fact that the banks were authorized to act as depositories of public money and as a market for United States Bonds. ${ }^{52}$ The Court expressly overruled the contention that the designation of these banks as fiscal agents and public depositories of the government was a mere pretext and that they had not been actually used as such, declaring that when Congress was acting within the limits of its constitutional authority it was not within the province of the Court to inquire into its motives. ${ }^{53}$

If, then, the principle enunciated in this decision were carried to its logical conclusion, it would seem that Congress could constitutionally create a corporation for almost any purpose by merely providing that.the corporation should act as a fiscal agent of the government. A glance at the laws creating a few of these corporations will demonstrate that this point has not been overlooked. The Reconstruction Finance Corporation is to act as a financial agent of the United States and as a depository for public moneys when so designated by the Secretary of the Treasury, ${ }^{54}$ as are also the Federal Home Loan Banks, ${ }^{55}$ Federal savings and loan associations and members of any Federal Home Loan Bank, ${ }^{56}$ the Federal Savings and Loan

48. 255 U. S. I80 (Ig2I). In Baltimore Nat'1 Bank v. State Tax Comm., 297 U. S. 209 (1936), involving the taxability under Maryland law of shares of stock owned by the R. F. C. in the Baltimore National Bank, the Court did not decide the constitutionality of the Reconstruction Finance Corporation. "We assume, though without deciding even by indirection, that within MicCulloch v. Maryland ... a corporation so conceived and operated is an instrumentality of government without distinction in that regard between one activity and another." Id. at $2 \mathrm{II}$.

49. 39 Stat. 362 (I916), т2 U. S. C. A. §671 (1934).

50. 39 STAT. 366 (Igr6), I2 U. S. C. A. $\$ 678$ (I934).

5I. Smith v. Kansas City Title \& Trust Co., 255 U. S. I80, 208 (I92I).

52. Id. at $2 \mathrm{Ir}$.

53. Id. at 2 IO.

54. 47 Stat. Io (1932), I5 U. S. C. A. \$612 (Supp. I936).

55. 47 Stat. 736 (I932), I2 U. S. C. A. § I434 (I934).

56. 48 Stat. I32 (I933), I2 U. S. C. A. $\$$ I 464 (k) (I934). 
Insurance Corporation, ${ }^{57}$ the Federal Credit Unions, ${ }^{58}$ the National Mortgage Associations, ${ }^{59}$ the Federal Deposit Insurance Corporation, ${ }^{60}$ the Central Bank for Cooperatives, the Production Credit Corporations, Production Credit Associations, the Federal Farm Mortgage Corporation, and Banks for Cooperatives. ${ }^{61}$ It does not seem reasonable to suppose that the Court will sustain all of the congressional enactments creating these corporations merely on the ground that they are fiscal agents and depositories of public funds. In at least one notable case ${ }^{62}$ the Court was not blinded by the fact that Congress had designated a penalty as a tax. Of course the argument does carry considerable weight when applied to government corporations which actually are useful in carrying out the fiscal powers of the government, such as the Bank of the United States. Thus an examination of each particular corporation from a functional viewpoint is required in order that its constitutional propriety may be ascertained. It is a question not of Congressional motive but of what Congress has actually done. Congress cannot preclude judicial scrutiny by a mere declaration or by a legislative finding. ${ }^{63}$ And the Court will probably not be very much impressed by the stereotyped paragraphs designating these various corporations as fiscal agents when in fact they are not. A great many of the recent government-owned corporations are principally concerned with finance and credit. It reasonably may be urged that these can be sustained under the power of Congress to coin money and to regulate its value. ${ }^{64}$ This would necessarily require a holding that Congress can regulate the nation's credit in order that the value of money may be fully regulated. Government corporations lending money and also those insuring bank accounts may be held necessary and proper to the maintenance of a sound monetary system.

Those government corporations which are not engaged with financing and the extension of credit but which were formed with an eye toward the regulation of private business or the providing of relief require a different justification. This class would include T. V. A., the Federal Subsistence Homesteads Corporation, the Federal Surplus Commodities Corporation, the Public Works Emergency Housing Corporation, and the Prison Industries Corporation. The Court has sustained the power of Congress to incorporate interstate railways ${ }^{65}$ and to create a corporation to build an interstate

57. 48 Stat. 1256 (1934), I2 U. S. C. A. § I725 (d) (1934).

58. 48 Stat. I222 (1934), i2 U. S. C. A. \$ I767 (1934).

59. 48 StAT. I255 (I934), I2 U. S. C. A. \$ I723 (I934).

60. 48 Stat. 168 (I933), I2 U. S. C. A. $\$ 264$ (n) (I934).

6I. 48 Stat. 267 (I933), I2 U. S. C. A. \$II38 (a) (r934).

62. Bailey v. Drexel Furniture Co., 259 U. S. 20 (Ig22).

63. St. Joseph Stock Yards Co. v. United States, 298 U. S. 38, 5I (r936).

64. U. S. Const. Art. I, § \&, cl. 5 .

65. California v. Central Pac. R. R., I27 U. S. I (I888). 
bridge ${ }^{68}$ under the commerce power. ${ }^{67}$ But it has also held that the generation of electricity is not interstate commerce although it immediately crosses state lines. ${ }^{88}$ And the activities of the Public Works Emergency Housing Corporation are even further removed from interstate commerce since houses generally have a fixed locale.

The activities of some government corporations may be justified under the much discussed general welfare clause. ${ }^{69}$ Without discussing the different theories in respect to this clause, suffice it to say that the Court has specifically adopted the interpretation placed upon it by Hamilton, as opposed to the view taken by Madison. ${ }^{70}$ Thus Congress has the power to spend money for the general welfare and is not limited by the grant of enumerated powers. ${ }^{71}$ The only qualification of this spending power is that it must be limited to public purposes. For instance, the power to lay taxes for the common defence and the general welfare could not be constitutionally employed for the purpose of "propogating Mohammedanism among the Turks". ${ }^{2}$ But just what constitutes a "public purpose" as distinguished from a "private purpose" was not settled by the only case discussing this clause. ${ }^{73}$ However, we do know that if a government corporation is to be sustained under the clause, it must be a spending agency of the Federal Government. Here, as in the discussion of the authority of Congress to create corporations under the fiscal powers, we must be careful not to let the pretext of words impress the stamp of validity upon an unconstitutional activity. Assuming, then, that Congress may validly create corporations under the spending power, how about corporations which are conducted on a commercial basis in which the United States holds the stock? Congress cannot be said to be spending money when it appropriates money to buy stock, since presumably the stock has some value. ${ }^{74}$ This differs greatly

66. Luxton v. North River Bridge Co., I 53 U. S. 525 (I894).

67. U. S. Const. Art. I, \$ 8, cl. 3 .

68. Utah Power \& Light Co. v. Pfost, 286 U. S. I65 (I932).

69. U. S. Const. Art. I, \&8, cl. I : "The Congress shall have Power To lay and collect Taxes, Duties, Imposts and Excises, to pay the Debts and provide for the common Defence and general Welfare of the United States; . ."

70. United States v. Butler, 297 U. S. I, 66 (1936).

$7 \mathrm{r}$. "While, therefore, the power to tax is not unlimited, its confines are set in the clause which confers it, and not in those of section 8 which bestow and define the legislative powers of the Congress. It results that the power of Congress to authorize expenditures of public moneys for public purposes is not limited by the direct grants of legislative power found in the Constitution." Ibid.

72. See I Story, Constirution (5th ed., I891) $\$ 922$.

73. United States v. Butler, 297 U. S. I, 68 (1936): "We are not now required to ascertain the scope of the phrase 'general welfare of the United States' or to determine whether an appropriation in aid of agriculture falls within it." The court here adopted the view urged by the author in The Nerw Deal and the Public Money (1935) 23 GEo. L. J. 155, that the Hamiltonian and not the Madisonian theory was correct as to the constitutional authority of the Congress to appropriate public money, with which compare Alabama Power Co. v. Ickes, decided May I0, I937, by the Court of Appeals for the District of Columbia. See also Brabner-Smith, The Hoosac Mills Case and Our Founding Fathers (I936) 25 GDo. L. J. 48,54 .

74. United States v. Railroad Co., I7 Wall. 322 (U. S. I872). 
from giving grants in aid to the states. ${ }^{75}$ A government corporation which is operated upon a profit-making basis for the benefit of the United States as shareholder could scarcely be called a spending agency. ${ }^{76}$

\section{Incorporation under State Statutes}

We have yet to consider those corporations created pursuant to executive order under the general incorporation laws of various states. ${ }^{77}$ The authority of the Executive to create government corporations under state law is said to be found in statutes authorizing him to establish such agencies as he may find necessary. Thus, under Title II of the N. R. A. ${ }^{78}$ it was provided that, in order to effectuate the purposes of the act, " . . . the President is hereby authorized . . . to establish such agencies . . . as he may find necessary . . . ." 79 The Public Works Emergency Housing Corporation, created under the laws of Delaware, was established pursuant to an Executive Order under the authority of this section. ${ }^{80}$ In view of some recent pronouncements from high authority concerning the delegation of power, ${ }^{81}$ questions may well be raised as to such procedure. In the Schechter case a similar problem was discussed. The President was to make a finding that a code "will tend to effectuate the policy of this title." The Court said, "While this is called a finding, it is really but a statement of an opinion as to the general effect upon the promotion of trade or industry of a scheme of laws." 82 So if the President believed that a corporation would effectuate the purpose of the Act, he could establish one upon his own motion with-

75. E. g., the Maternity Act, 42 STAT. 224 (I92I), 42 U. S. C. A. § I6I (1928), which authorized appropriations from the national treasury to be apportioned among such states as should accept and comply with its provisions, for the purpose of cooperating with them to reduce maternal and infant mortality, and to protect the health of mother and infants. See BECK, OUR WONDERLAND OF BUREAUCRACY (I932) I97, 209.

76. This ought to hold true even where there is no stock issued, as in T. V. A., since stock is supposed to represent, in some degree, the actual or potential value of a company.

77. E. g., the Commodity Credit Corporation, chartered under the laws of Delaware. EXEC. ORDER No. 6340, Oct. I7, 1933.

78. 48 Stat. 200 (1933), 40 U. S. C. A. \$ 40r (Supp. I936).

79. 48 Stat. 200 (I933), 40 U. S. C. A. \$ 40I (a) (Supp. 1936). See also 48 Stat. 205 (1933), 40 U. S. C. A. $\$ 408$ (Supp. 1936), in which $\$ 25,000,000$ is made available to the President to provide for aiding the redistribution of the overbalance of population in industrial centers, the money ". . . to be used by him through such agencies as he may establish ..." Pursuant to order of the Secretary of the Interior (Dec. 2, I933) the Federal Subsistence Homestead Corporation was created under Delaware laws. The Secretary of the Interior received his authority by virtue of an Executive Order delegating to him the power to "establish such agencies ... as he may find necessary ..." EXec. Order No. 6252, Aug. 19, 1933 .

So. Exec. Order No. 6470, Nov. 29, 1933.

8r. Panama Refining Co. v. Ryan, 293 U. S. 388 (I935) ; Schechter Poultry Corp. v. United States, 295 U. S. 495 (1935); see also Franklin v. Tugwell, 85 F. (2d) 208 (App. D. C. I936), holding the Emergency Relief Appropriation Act of 1935 unconstitutional as an invalid delegation of powers. But $c f$. the opinions of the same court in Alabama Power Co. v. Ickes and Iowa City Light \& Power Co. v. Ickes, decided May Io, 1937.

82. Schechter Poultry Corp. v. United States, 295 U. S. 495, 538 (1935). See McGuire, Adninistrative Lannaking (I936) I85 ANNALs 73, 84; Report of the Special Committee on Adninistrative Law (I936) 6I A. B. A. REP. 720. 
out an administrative agency to assist him, as was the case in approving codes of fair competition. ${ }^{83}$ It is plain that the statute did not require the President to make findings of fact before establishing a government corporation under Title II of the N. R. A. Nor was he required to make any statement as to his reasons for establishing a corporation. The power to establish agencies does not require that a corporation be established. An "agency" could easily be any of the many other forms of business associations. The essence of Title II of the N. R. A. was to prepare and finance, through any agency he might create, a vast system of public works. ${ }^{84}$ The President could construct, finance or aid any public works project included in the public works program. He had unfettered discretion in choosing any number, type, or class of agency. Moreover he was not directed to establish agencies but rather was permitted to do so if he chose. Such a roving commission to pick and choose was condemned in the Schechter ${ }^{85}$ and Panama ${ }^{86}$ cases.

It may also be questioned whether Congress intended that the President should have power to create a corporation rather than the usual form of government commission or board when it authorized him to establish such agencies as he should find necessary. This is particularly important in view of the difference in legal status between a government corporation and a government department. ${ }^{87}$ The point has never been judicially decided in spite of the fact that several similar war-time corporations were involved in litigation. The Attorney General is of the opinion that under Title II of the N. I. R. A. the President not only has the power to create government corporations but that he may create them under the laws of a state. ${ }^{88}$ On the other hand, in a letter to the Federal Emergency Administrator of Public Works, Comptroller General McCarl stated that there was room for doubt on the matter, but that in order not to place any unnecessary restraint on those administering the law he felt justified in withholding objections. ${ }^{89}$ The Attorney General took the position that, since Congress knew of the practice of the President's establishing corporations by executive order during the War, they must be deemed to have vested this measure of discretion in the President.

Viewing the matter in its fundamental aspect, the national government is allowing the state government to create a federal instrumentality whose powers and duties are determined by the laws of the state of incorporation.

83. Schechter Poultry Corp. v. United States, 295 U. S. 495, 539 (I935).

84. 48 Stat. 201 (I933), 40 U. S. C. A. $\$ \$ 402,403$ (Supp. I936).

85. 295 U. S. 495,538 (I935).

86. 293 U. S. 388,432 (r 935 ).

87. See United States ex rel. Skinner \& Eddy Corp. v. McCarl, 275 U. S. I (Ig27).

88. 37 Ops. Atr'y GeN. (I934) 437.

89. 78 Cong. Rec. I053 (1934). 
This opens up a vast field of conflict of laws necessarily incident to such a use of a state corporation. It would seem that uniformity is even more to be desired in the structure of government than in the field of maritime law..$^{90}$ It is true that Congress can expressly adopt the provisions of various state laws upon certain subjects, ${ }^{91}$ but in the cases of corporations formed under state laws, Congress has said merely that the President may establish such agencies "as he may find necessary". If constitutionally a federally owned and controlled corporation may be organized under state laws, may such corporations operate in states other than the original state? And may the Federal Government go to the states for additional power otherwise than in the prescribed mode for constitutional amendment? ${ }^{92}$

Recently the Court held that the conversion of a state building and loan association into a federal association was of no effect as against the protest of the state. ${ }^{93}$ The building and loan association was classed as "quasi-public" but much of the reasoning may be applicable to ordinary corporations. The Court said:

"Wisconsin, planning these agencies (building and loan associations) in furtherance of the common good and purposing to preserve them that the good may not be lost, is now informed by the Congress, speaking through a statute, that the purpose and the plan shall be thwarted and destroyed. By the law of the state, associations such as these may be dissolved in ways and for the causes carefully defined, in which event the assets shall be converted into money and applied, so far as adequate, to the payment of the creditors. By the challenged Act of Congress, the same associations are dissolved in other ways and for other causes, and from being creatures of the state become creatures of the nation. In this there is an invasion of the sovereignty or quasisovereignty of Wisconsin and an impairment of its public policy, which the state is privileged to redress as a suitor in the courts so long as the Tenth Amendment preserves a field of autonomy against Federal encroachment." 94

90. Cf. Knickerbocker Ice Co. v. Stewart, 253 U. S. I49 (I920), holding invalid an act of Congress making workmen's compensation laws of the several states applicable to injuries received in maritime work.

9r. Cooley v. Bd. of Wardens, I2 How. 298 (U. S. I85I) ; Clark Distilling Co. v. Western Md. Ry., 242 U. S. 3II (I9I7).

92. The President's Committee on Administrative Management in the Government of the United States reported that: "In times of war and other national emergency, corporations have been chartered under the laws of the several States by executive officers of the Government to further some activity authorized by legislation.

"There are great advantages in certainty of operation if the Federal charter is used wherever possible. There is grave question as to the advisability of the continued use of State charters by the Federal Government and further study of this problem is recommended. There is reason to believe that unnecessary conflicts of State and Federal jurisdiction are engendered and that the use of the State charters threatens the Federal Government with the impairment or destruction of its control over its instrument in the face of State hostility. Considerable uncertainty and litigation have undoubtedly arisen in this connection." SEN. Doc. No. 8, 75th Cong., Ist Sess. (I937) 75.

93. Hopkins Fed. Savings \& Loan Ass'n v. Cleary, 296 U. S. 3I5 (I935).

94. Id. at 337 . 
Whatever else the case stands for, it does stand for the fact that a state has some rights in the corporations created under its own laws. If this is true, what about the other states which have not consented to the invasion of the Federal Government except in accordance with the power delegated to it in the Constitution? However, the National Government would be submitted to state restrictions by the creation of government corporations under state law. This would appear inconsistent with the theory that the Federal Government should have exclusive power over its own instrumentalities.

The question as to the power of removal of directors of corporations which the President has caused to be created by executive order may become of great practical importance. While in practice, the directors usually occupy some other office in the executive branch of the government, this is not a legal requirement. This is an undeveloped field of governmentowned corporations, and it remains to be seen whether the President can remove, or control such officers in any way not expressly provided by the statute creating the corporation. If the directors are also executive officers, he might remove them as executive officers, but could he remove them as officers of the corporation when the statute of its creation does not so provide? As to those corporations which are created directly by Act of Congress and whose directors are appointed by the President by and with the advice and consent of the Senate, ${ }^{95}$ the President could not remove them at his pleasure ${ }^{96}$ unless authority to that effect was contained in the statute of their creation.

Could a government corporation formed under the laws of a state operate in other states without their consent? No cases involving the precise point have been discovered, but probably it could not if the corporation were performing functions of the Federal Government and the other states were objecting. However, in a case involving the power of a state to require a foreign corporation to take out a license as a condition to doing business within the state the Court said:

"The only limitation upon this power of the State to exclude a foreign corporation from doing business within its limits, or hiring offices for that purpose, or to exact conditions for allowing the corpora-

95. The Act creating the R.F.C. also establishes a definite term of two years for the directors and specifies that not more than four of the seven directors may be members of the same political party. 47 STAT. 5 (1932), I5 U. S. C. A. \$603 (Supp. 1936).

96. The President may not remove a member of the Federal Trade Commission at will. Humphrey's Exec. v. United States, 295 U. S. 602 (1935). The act under which the commissioners are appointed resembles very closely the act creating the $R$. F. C. The reasoning in the Humnphrey case should apply since the officers are not performing strictly executive duties. The President's Committee on Administrative Management in the Government of the United States recommended that: "All Government corporations should likewise be brought under supervision and control through transfer into regular departments. They should be established therein as semi-autonomous divisions, with extensions to them of such budgetary, financial, and personnel supervision or control as may be appropriate in any given case." SEN. Doc. No. 8, 75th Cong., Ist Sess. (I937) 76. 
tion to do business or hire offices there, arises where the corporation is in the employ of the federal government, or where its business is strictly commerce, interstate or foreign. The control of such commerce, being in the federal government, is not to be restricted by state authority." 97

In Arizona v. California ${ }^{98}$ the Court held that the United States has power to construct a dam across a navigable river in order to improve navigation and need not first obtain approval of its plans by the state in which the dam is to be located, even though this be expressly required by a statute of the state. The State of Utah considers the R. F. C. Mortgage Company, a Maryland corporation, as a federal governmental agency, and hence it is not required to pay the taxes and fees usually required of foreign corporations.99

There is little doubt but that a federally owned state corporation may be sued in state courts since the state laws provide for suits against corporations ${ }^{100}$ and since corporations created by direct act of Congress may be made subject to suit. ${ }^{101}$ Some of the war-time corporations chartered under state laws have been held liable to suit. One of the most important cases to this effect is Sloan Shipyards Corporation v. United States Shipping Board Emergency Fleet Corporation. ${ }^{102}$ Here an action was brought against the Fleet Corporation for breach of contract. The District Court held that it was in reality a suit against the United States and should therefore have been brought in the Court of Claims, but the Supreme Court held that the suit could be brought in the ordinary national and state courts just as though it were a suit against a private corporation. Numerous cases have since held government corporations chartered under state law liable to suit. ${ }^{103}$ Whatever the reasons advanced for holding them so liable, the rules governing the fair transaction of business require that when the government deals with indi-

97. Mr. Justice Field in Pembina Mining Co. v. Pennsylvania, I25 U. S. I8r, I90 (I887).

98. 283 U. S. 423 (I93r). The Court there said (at 45I-452), "The United States may perform its functions without conformity to the police regulations of a State."

99. Op. Att'y Gen of Utah, June 5, 1935. C. C. H. Bank L. Serv. II 13,508. A similar conclusion was reached by the Supreme Court of the United States in Rogers v. Graves, 57 Sup. Ct. 259 (U. S. I937), as to the unconstitutionality of a state tax on income earned by counsel for the Panama Railroad Company.

100. See Puget Sound Mach. Depot v. United States Shipping Bd. Emer. Fleet Corp., 293 Fed. 768 (W. D. Wash. 1923) ; Haines v. United States Shipping Bd. Emer. Fleet Corp., $268 \mathrm{~Pa}$. 92, II0 At1. 788 (I920), $275 \mathrm{~Pa}$. 260, I18 At1. 909 (I922).

ror. Inland Waterways Corp., 43 STAт. 360 (I924), 49 U. S. C. A. § I5I (I928); R. F. C., 47 Stat. 5 (1932), I5 U. S. C. A. \$601 (Supp. 1936); T. V. A., 48 STat. 58 (I933), I6 U. S. C. A. \$ 83I (Supp. I936) ; F. D. I. C., 49 STAT. 684 (I935), I2 U. S. C. A. \$264 (Supp. I936) ; Fed. Farm Mortgage Corp., 48 STAT. 334 (I934), I2 U. S. C. A. § I020 (Supp. 1936).

I02. 258 U. S. 549 (1922).

ro3. See Schnell, Federally Ozened Corporations and Their Legal Problents (1935) I4 N. C. L. REv. 238, 337 ; Thurston, Government Proprietary Corporations (I935) 2I VA L. REV. 35I, 465 . 
viduals on a commercial basis there should be no undue advantage given to one of the parties. ${ }^{104}$

A more interesting question is whether a state chartered federal corporation should be allowed to remove a suit to a federal court on the ground that it is a case arising under the Constitution and laws of the United States. ${ }^{105}$ The judicial code provides that "No district court shall have jurisdiction of any action or suit by or against any corporation upon the ground that it was incorporated by or under an Act of Congress. This section shall not apply to any suit, action, or proceeding brought by or against a corporation incorporated by or under an Act of Congress wherein the Government of the United States is the owner of more than one-half of its capital stock." 106 The stock of a state-chartered government corporation is generally wholly owned by the United States, but the section quoted does not confer absolute federal jurisdiction of cases involving government owned corporations. ${ }^{107}$ The other requisites of federal jurisdiction must therefore appear.

In the recent case of Gully $v$. First National Bank in Meridian ${ }^{108}$ this question of federal jurisdiction based on the ground of a suit arising under the Constitution and laws of the United States was carefully treated. The Bank in Meridian had taken over the assets of the Bank of Meridian under a contract whereby the debts and liabilities of the insolvent grantor were assumed by the grantee. Among the liabilities so assumed were moneys owing the state tax collector, for which he brought suit in the courts of Mississippi. A petition for removal was filed by the bank on the ground that it was a suit arising under the Constitution and laws of the United States. The Circuit Court of Appeals so held, but the Supreme Court reversed this holding, stating that the suit was built upon a contract whose obligation had

I04. "If the sovereign thus chooses as its agent a state corporation which can be sued it cannot ipse dixit deprive one injured of the right to sue. The State of Delaware allowed defendant to be created, but as a condition of its creation and existence it afforded the right to anyone to sue the corporate being which it thus created." ". . . when the sovereign uses an agency created not by itself but under a state statute, he takes his agent as he finds it." Hand, J., in Federal Sugar Refining Co. v. United States Sugar Equalization Bd., 268 Fed. $575,584,586$ (S. D. N. Y. I920). See also Gould Coupler Co. v. United States Shipping Bd. Emer. Fleet Corp., 26I Fed. 7I6, 7I8 (S. D. N. Y. I9I9) : Moreover it is in general highly desirable that, in entering upon industrial and commercial ventures, the governmental agencies used should, whenever it can fairly be drawn from the statutes, be subject to the same liabilities and to the same tribunals as other persons or corporations similarly employed. The immunity of the sovereign may well become a serious injustice to the citizen, if it can be claimed in the multitude of cases arising from governmental activities which are increasing so fast."

I05. Some other important questions of federal jurisdiction are: Are federal corporations of states to be considered as citizens of the state in order to give diversity? Olson v. United States Spruce Production Corp., 267 U. S. 462 (I925). How should venue of actions be determined? Panama R. R. v. Vasquez, 27r U. S. 557 (I926); Wallace v. United States Shipping Bd. Emer. Fleet Corp., 5 F. (2d) 234 (W. D. Wash. 1925).

I06. 43 STat. 94r (I925), 28 U. S. C. A. \$ 42 (1927).

107. Beicher v. Aetna Life Ins. Co., 3 Fed. Supp. 809 (W. D. Tex. I933).

I08. 57 Sup. Ct. 96 (1936). 
its genesis in the law of Mississippi and that there was no connection between the enforcement of such a contract and the existence of a controversy under the federal law. The Bank also argued that the Mississippi tax was upon a national bank and would be void unless permitted by Congress. The Court held that, although there is a federal law permitting such taxation, this does not create a question arising under federal law, the federal law being "evidence to prove the statute valid." 109 The Court reaffirmed the test laid down in Puerto Rico v. Russell \& Co., ${ }^{110}$ saying "The federal nature of the right to be established is decisive-not the source of the authority to establish it.' Here the right to be established is one created by the state. If that is so, it is unimportant that federal consent is the source of state authority. To reach the underlying law we do not travel back so far." 111

It would therefore seem that an ordinary lawsuit against a federal corporation chartered under state law would not be such a suit arising under the Constitution or laws of the United States as to be removable from a state to a federal court. When these corporations enter into contracts with individuals the obligations of such contracts are fixed by the state law. When Congress used the incorporation laws of a state, it should be held to have consented to suit in the state courts. ${ }^{112}$ Nor would such a holding be inconsistent with the rule that a suit by a corporation by a direct act of Congress is one within the jurisdiction of the federal courts. Moreover, both Congress and the Court have manifested a desire to restrict this rule even in suits against federally chartered corporations. ${ }^{113}$

One of the most difficult problems in the entire field is that of the power of a state to tax a federal corporation formed under state law. It is fundamental, of course, that a federal instrumentality is immune from state taxation, ${ }^{114}$ unless Congress has consented to the tax. ${ }^{115}$ Although there are cases involving the taxability of federally incorporated railways ${ }^{116}$ and

rog. $I d$. at 99.

IIO. 288 U. S. 476 (I933).

III. 57 Sup. Ct. 96, at 99. Much of our social legislation is intimately connected with this problem. Shortly after the passage of the Social Security Act the Commissioner of Internal Revenue ruled that the employees of National Banks are "instrumentalities" of the Federal Government. XV Int. Rev. Bull., No. 30, at 30 (I936). Also, at a later date he decided that employees of state banks affiliated with the Federal Reserve System likewise do not come within the terms of the Social Security Statute. XV Int. Rev. Bull., No. 40, at I5 (I936). All that is necessary to take the other state banks out of the said law is for them to affiliate with the Federal Reserve System.

Ir2. "It is alleged that, upon 'the direction' of the President, defendant was incorporated. - . Neither the Executive nor any person acting with authority under him had the power to change the obligations, rights or liabilities of a corporation which was the creature of the statute; i. e., the creature of the sovereign state of Delaware." Federal Sugar Refining

Co. v. United States Sugar Equalization Bd., 268 Fed. 575, 584 (S. D. N. Y. I920).

II3. Puerto Rico v. Russell \& Co., 288 U. S. 476, 485 (I933).

II4. McCulloch v. Maryland, 4 Wheat. 316 (U. S. ISIg).

II5. Baltimore Nat'l Bank v. State Tax Comm., 297 U. S. 209, 2II (I936).

II6. Thompson v. Pacific R. R., 9 Wall. 579 (U. S. I869); Railroad v. Peniston, I8 Wall. 5 (U. S. I873). 
banks ${ }^{117}$ by the states, these cases are scarcely applicable to the present question since the businesses were privately owned. The cases most nearly applicable are those involving the attempts of states to tax war-time federal corporations formed under state laws. The Court consistently refused to allow state taxation of these national agencies. However, the language in these cases is notable for the emphasis placed on the existence of a war-time emergency. For this reason a great deal of caution should be used in applying the reasoning of those cases to modern government corporations engaged in commercial activities.

In Clallam County $v$. United States ${ }^{118}$ the Court held an attempt by the county to tax the property of the Spruce Production Corporation invalid. The corporation was a Washington corporation whose stock was held by the United States. The State sought to justify the tax on the ground that although taxation of the agency may be taxation of the means employed by the government and hence invalid, taxation of the property of the agent is not necessarily taxation of the means. The Court answered this contention by saying:

"But it may be, and in our opinion clearly is when as here not only the agent was created but all the agent's property was acquired and used, for the sole purpose of producing a weapon for the war. This is not like the case of a corporation having its own purposes as well as those of the United States and interested in profit on its own account. The incorporation and formal erection of a new personality was only for the United States to carry out its ends." 119

In United States Spruce Production Corporation v. Lincoln County ${ }^{120}$ a county tax levied on the property of the Spruce Corporation was held invalid, the Court saying that although some cases had permitted state taxation of a federal corporation, in this instance the property of the Spruce Corporation was itself the very means through which the corporation was able to perform the functions required by the government. The court also held that if property is exempt where the title is in the United States (principal) it is also exempt when the title stands in the name of the Spruce Corporation (agent). ${ }^{121}$ In New Brunswick v. United States ${ }^{122}$ the Court held that land standing in the name of the United States Housing Corporation (a state corporation) could not be taxed by the city, even though the corporation held the title only for purposes of security.

II7. Owensboro Nat'1 Bank v. Owensboro, 173 U. S. 664 (I899) ; Smith v. Kansas City Title and Trust Co., 255 U. S. I80 (I92I).

II8. 263 U. S. 34I (I923).

II9. Id. at $344-345$.

I20. 285 Fed. 388 (D. Ore. I922).

I21. Id. at 390 . For a full list of cases holding alleged agencies of the United States not exempt from taxation and holding the tax void, see Schlosser v. Welch, 5 Fed. Supp. 993, 999-IO0I (D. S. D. I934).

122. 276 U. S. 542 (1928). 
Thus we have at least two Supreme Court cases holding that local taxing authorities may not impose taxes on these "weapons for the war" even though they came into being via state incorporation laws. But, as was stated before, the reasoning of these cases may not apply to present day "federal-state" corporations, especially where they are not engaged in carrying out strictly Federal governmental functions. One ground upon which these corporations may well be held liable to state taxation is that the national government has used the same method of creating a corporation as private persons would have done. Thus the corporation is a creature of the state as well as of the United States. ${ }^{123}$ The United States has descended to the level of private incorporators and is therefore subject to the laws of the incorporating state. If Congress had wished to confer sovereign privileges on these agencies it would have incorporated them directly as it has done in many cases. Chief Justice Marshall once remarked: "It is, we think, a sound principle, that when a government becomes a partner in any trading company, it divests itself, so far as concerns the transactions of that company, of its sovereign character, and takes that of a private citizen. Instead of communicating to the company its privileges and prerogatives, it descends to a level with those with whom it associates itself, and takes the character which belongs to its associates, and to the business which is to be transacted." 124 Although this statement was made in reference to the liability to suit of a corporation in which the State of Georgia was a stockholder together with some private individuals, nevertheless the argument would have force in regard to state taxation of state incorporated federal corporations. Furthermore, the principle holds true not only where a government is participating with private persons in a corporation, but also where the government is the sole stockholder. ${ }^{125}$

It has been suggested that the same principles in regard to national taxation of state-controlled corporations should apply in the case of state taxation of national corporations, i. e., that a distinction should be made between governmental and commercial activities. If national corporations are engaged in the latter they should be taxable by the states. ${ }^{126}$ This theory finds its inception in South Carolina v. United States. ${ }^{127}$ This case upheld the right of the United States to impose a license tax on liquor dispensaries in South Carolina although the business was a state monopoly and the dispensaries were state agencies. The Court leaned heavily on the distinction

123. See letter from the Comptroller General to the Federal Emergency Administrator of Public Works [78 CoNG. REc. I053 (I934)], wherein he suggests the possibility of subjecting government agencies and property to state taxation. See also 33 Ors. ATr'y GEN (I923) 570.

I24. Bank of United States v. Planter's Bank, 9 Wheat. 904, 907 (U. S. I824).

I25. Bank of Kentucky v. Wister, 2 Pet. 3 IS (U. S. I829).

126. Thurston, Government Proprietary Corporations (1935) 2I VA. L. Rev. 35I, 482. I27. I99 U. S. 437 (I905). 
between the governmental and commercial functions of a state. The Court also pointed out that the states might take over all industry and that if federal license taxes could not be imposed on these businesses, the national government would be deprived of its revenue.

While the distinction between governmental and commercial activity may well be made in the cases of individual states, it is of doubtful weight when applied to the national government. In other words, it is constitutionally proper for a state to engage in private business; but where should we find authority for the Federal Government to operate, say, all of the shoe manufacturing of the United States? If in the field of state taxation of federal corporations we allow taxes on what is commercial and disallow on what is governmental, we may find that the commercial function is unconstitutional before we get a chance to tax it. Further, the distinction between what is a "proprietary" and what a "public" function is most confused in cases concerning the tort liability of municipal corporations. Possibly the chaos would be equally great should we seek to draw it in the field of state taxation of federal corporations.

Either the federal corporations chartered under state law must be held to have descended to the level of private corporations and thus to have become taxable by the states, or they must be considered as instrumentalities of the United States and, as such, entitled to immunity from state taxation. ${ }^{128}$ If the latter proves to be the rule, the distinction in the field of taxation between government corporations created by direct act of Congress and those created under state law pursuant to executive order will be negligible. The development during the next few years of this aspect of the law of government by corporations will be of great interest and importance.

128. There is some indication toward immunity from state taxation of federal corporations, even though organized under state laws, by the holding in Rogers v. Graves, 57 Sup. Ct. 259 (U. S. I937), where it was held that income derived from employment by the Panama Railroad Company was not subject to state taxation. However, the court apparently attempted to ground its decision on the point that the railroad company was operated as an adjunct to the Panama Canal, which was a governmental function. The railroad company owned a fleet of steamships and engaged in the transportation of freight from New York to Central America for hire. It is not too much to say that this entire situation is considerably confused, and there appears no means of knowing at this time what rule will be finally evolved. 